\title{
Evaluation and Analysis of Environmental Noise Pollution in Seven Major Cities of India
}

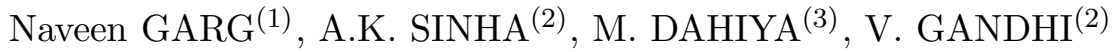 \\ R.M. BHARDWAJ ${ }^{(2)}$, A.B. AKOLKAR ${ }^{(2)}$ \\ (1) CSIR-National Physical Laboratory \\ New Delhi - 110 012, India; e-mail: ngarg@nplindia.org \\ (2) Central Pollution Control Board, Parivesh Bhawan \\ East Arjun Nagar, Delhi - 110 032, India \\ (3) NIT Kurukshetra \\ Kurukshetra - 136 119, India \\ (received March 3, 2016; accepted January 17, 2017)
}

\begin{abstract}
The paper describes the noise monitoring data acquired from the pilot project on the establishment of National Ambient Noise Monitoring Network (NANMN) across seven major cities in India for continuous noise monitoring throughout the year. The annual average $L_{\text {day }}(06-22 \mathrm{~h})$ and $L_{\text {night }}(22-06 \mathrm{~h})$ values observed in year 2011-2014 for the 35 locations under study in which 14 locations are in commercial zone, 5 in Industrial, 7 in residential and 9 in silence zones are described. The long-term noise monitoring shows that ambient noise levels have marginally increased for 29 sites $(82.9 \%)$ since past four years. The present study is focused on evaluation and analysis of environmental noise pollution at 35 noise monitoring sites in seven major cities of India and shall be instrumental in planning for the noise abatement measures for controlling the noise pollution in these sites.
\end{abstract}

Keywords: National Ambient Noise Monitoring Network $(N A N M N)$; day equivalent level, $L_{\text {day }}$; night equivalent level, $L_{\text {night }}$; day-night average sound level, $L_{\mathrm{dn}}$; equivalent continuous sound pressure level, $L_{\text {Aeq, } 24 \mathrm{~h}}$.

\section{Introduction}

The rapid urbanization and growth of urban population has led to many health challenges including the environmental air and noise pollution. Amongst all the pollution problems, noise is considered as an important environmental issue. Motor vehicles are the main sources of urban noise emission contributing about $55 \%$ to the total noise (BANERJEE et al., 2008; PANDYA et al., 2002; SinHA et al., 2003). The growing vehicular population gives rise to noise pollution and associated health effects and can cause both short-term and longterm psychological and physiological disorders. Noise is regarded as a pollutant under the Prevention and Control of Pollution Act, 1981 of India (MoEF 1981 Act). The World Health Organization (WHO) estimates that $10 \%$ of the world population is exposed to sound pressure levels that could potentially causes noise induced hearing loss (OISHI et al., 2011; BASNER et al., 2014). Environmental noise causes numerous psychological effects such as annoyance (ÖHRSTRÖM et al., 2004; Ouis, 2001; РАTHAK et al., 2008), anxiety, depression and serious health effects such a cardiovascular disease (BABISCH, 2008; BABISCH et al., 2005; Davies et al., 2012; JAMIR et al., 2014; WHOJRC, 2011; Selander et al., 2009). Noise has been found to have significant negative impact on children's blood pressure and mental health. Some studies show that people who are exposed to high road traffic noise levels have significantly higher prevalence of hypertension (CHANG et al., 2011). It is thus essential to conduct noise monitoring studies especially for the noisy spots so as to monitor the sound levels and devise suitable abatement measures for controlling the noise pollution. The European Environmental Noise Directives, 2002/49/EC requires all the member states to produce strategic noise mapping, estimate population exposure to noise, develop noise action plans and disseminate 
the noise information to the public (MURPHY et al., 2010; To et al., 2015). Studies have been conducted in the different parts of the world for monitoring the ambient noise and implementing the noise abatement measures to control them (LI et al., 2002; MorIALLAS et al., 2002; ZANNIN et al., 2002; CHAKRABARTY et al., 2006; Murphy et al., 2009; NAISH et al., 2010; DiNTRANS et al., 2013; HAMMER et al., 2014; ABBASPOUR et al., 2015; GARG et al., 2015a; CAI et al., 2015; MCALEXANDER et al., 2015). Also, validated road traffic noise models have been developed for predicting the traffic noise and noise mapping of cities (STEELE et al., 2001; GARG et al., 2015b; 2015c; FIEDLER et al., 2015). In India, the pilot project of National Ambient Noise Monitoring Network (NANMN) established by Central Pollution Control Board (CPCB) in the year 2011 covering 35 locations in seven metro cities (Delhi, Hyderabad, Kolkata, Mumbai, Lucknow, Bangalore and Chennai) is a great step for monitoring and analyzing the ambient noise levels and disseminating the noise information to the public. The Central Pollution Control Board in association with State Pollution Control Boards is continuously monitoring and analyzing the noise levels and working on devising and implementing the noise abatement measures for controlling the noise pollution in India.

The present work is an extension of the previously reported study (GARG, MAJI, 2016a) on the establishment of National Ambient Noise Monitoring Network $(N A N M N)$ across seven major cities in India for continuous noise monitoring throughout the year and analyzes the noise monitoring data acquired for the 35 sites for the year 2014 and past four years (2011-2014) to analyze and report the status of noise pollution at these sites in the past four years and consideration of noise abatement strategies to be implemented to bring the noise levels below the ambient noise standards. The focus of the present study is thus to:

- ascertain the annual average ambient noise levels of 35 sites and compare them with ambient noise standards of India,

- ascertain whether the current ambient noise standards are suitable for residential areas and areas within silence zones and suggesting the need of amendments required if any,

- analyze the difference of $L_{\text {day }}$ and $L_{\text {night }}$ levels so as to ascertain the severity of night noise levels in comparison to the day levels,

- recommend the suitability of $10 \mathrm{~dB}$ adjustment in $L_{\mathrm{dn}}$ in Indian scenario in the light of development of a noise annoyance model in terms of single-noise descriptor, and

- finding out the noise spots and planning for implementing suitable control measures to bring these levels below the ambient standards.
Although 35 monitoring locations are insufficient to represent the noise environment of the concerned cities, yet the present study is based on evaluation and analysis of continuous long-term noise levels acquired under the $N A N M N$ programme at these 35 sites, which is one of the first networks established in India with special budgetary allocations. It may be noted here that the day equivalent level, $L_{\text {day }}$ and night equivalent level, $L_{\text {night }}$ is calculated from the 24 hours noise data for each day of the year. The day-time is from 6.00 a.m. to 10.00 p.m., while the night time is considered from 10.00 p.m. to 6.00 a.m. The current ambient noise standards followed in India are in terms of $L_{\text {day }}$ and $L_{\text {night }}$ as shown in Table 1 . The silence zone is an area comprising not less than $100 \mathrm{~m}$ around hospitals, educational institutions, courts, religious places or any other area which is declared as such by the competent authority. Mixed categories of areas may be declared as one of the four mentioned categories in Table 1 by the competent authority (Noise Pollution Rules, 2000; CPCB report, 2011-12; NANMN brochure, 2011).

Table 1. Ambient air quality standards in respect of noise in India (Noise Pollution rules, 2000).

\begin{tabular}{|c|c|c|c|}
\hline \multirow{2}{*}{ Area code } & \multirow{2}{*}{ Category of area/zone } & \multicolumn{2}{|c|}{ Limits in $\mathrm{dB}(\mathrm{A}) L_{\mathrm{eq}}^{*}$} \\
\cline { 3 - 4 } & & Day time & Night time \\
\hline A & Industrial area & 75 & 70 \\
\hline B & Commercial area & 65 & 55 \\
\hline C & Residential area & 55 & 45 \\
\hline D & Silence zone & 50 & 40 \\
\hline
\end{tabular}

${ }^{*} L_{\text {eq }}$ denotes the time weighted average of the sound level in decibels in $A$-weighting.

\section{Material and methods}

The noise monitoring data is acquired from the pilot project on the establishment of National Ambient Noise Monitoring Network (NANMN) established in the year 2011 across the seven major cities in India for continuous noise monitoring throughout the year. The details of the project and instrumentation used can be found in reference (GARG, MAJI, 2016). The 35 locations under study constitute of 14 locations are in commercial zones, 5 in industrial, 7 in residential and 9 in silence zones. The Noise Monitoring Terminal manufactured and installed by Geónica Earth Sciences, Spain (Geonica website, www.geonica.com) is an automated system consisting of a sound level meter traceable to the national standards for continuously measuring the ambient noise through the year at 35 locations under study. The sound level data acquired is transmitted to National Noise Monitoring Centre, $N N M C$ located at CPCB Headquarters, Parivesh Bhawan, New Delhi whereby the data is received, processed and displayed. In addition, a website 
application, http://www.cpcbnoise.com, is developed to
disseminate the data in real time to the public for generating awareness towards reducing the noise pollution in different parts of the country (SGS Weather and Environmental Systems Pvt. Ltd, India website, www.sgsweather.com). The remote stations collect and store the data which is then transmitted via a GPRS communications system to the central database, where they are stored. The noise monitoring data can be accessed on the website, http://www.cpcbnoise.com, showing the daily ambient sound levels: $L_{\text {day }}$ value and $L_{\text {night }}$ values for all the 35 sites under consideration. Figure 1 shows the display of ambient noise levels at CPCB office reception at Parivesh Bhawan, New Delhi of seven cities of India. The scope of the NANMN project has been enhanced with the installation of 35 more stations in the same seven metropolitan cities since November, 2014. The Noise Monitoring Network now covers 70 locations in seven metropolitan cities of India and is a unique and one of the largest noise monitoring networks of its kind across the globe.
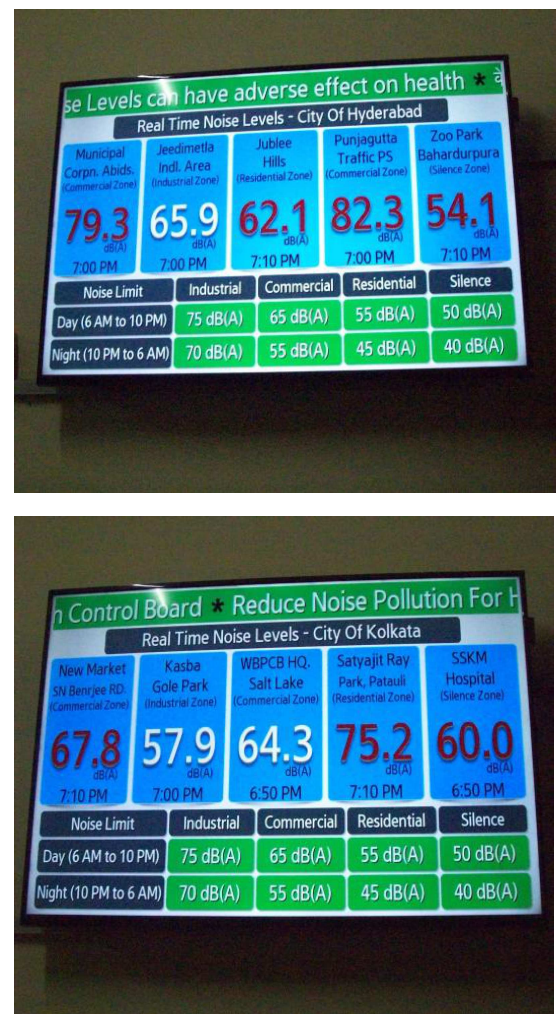

Fig. 1. Display of ambient noise levels at CPCB office reception at Parivesh Bhawan, New Delhi of seven cities of India.

\section{Analysis of noise pollution}

\subsection{City wise analysis}

The ambient noise levels: day equivalent level, $L_{\text {day }}$ and night equivalent level, $L_{\text {night }}$ were observed for all the 35 sites and compared to the ambient noise standards. Table 2 shows the annual average ambient levels, $L_{\text {day }}$ and $L_{\text {night }}$ for the past years, 2011-2013 as reported earlier in (GARG, MAJI, 2016) and for the year 2014 the annual average ambient levels for 35 noise monitoring stations installed under NANMN programme across seven major cities in India. The city wise and zone wise analysis of annual average ambient levels, $L_{\text {day }}$ and $L_{\text {night }}$ is conducted to identify the noisy spots for implementation of suitable noise abatement measures. Also, the difference of $\left(L_{\text {day }}-L_{\text {night }}\right)$ for all the zones in past four years (2011-2014) is analyzed to ascertain the severity of night noise levels in comparison to the day levels as reported earlier (GARG, MAJI, 2016) and consider the suitability of $10 \mathrm{~dB}$ night time adjustment in day-night average sound level, $L_{\mathrm{dn}}$ that accounts for the increased sensitivity to noise at night, the expectation that the night time noise will be lower than during the day and for sleep disturbance protection is not appropriate in such a scenario. Day-night average sound level, $L_{\mathrm{dn}}$ and dayevening-night average sound level, $L_{\text {den }}$ is the widely used noise descriptor recommended in many studies for developing exposure-effect relationship (EU's Future Noise Policy, 2002; Miedema et al., 1998; Schomer, 2002; 2005).

\subsubsection{Delhi city}

It is observed that there is a marginal increase in ambient noise levels in Delhi city since the past four years. The maximum increase in $L_{\text {day }}$ value since past four years is $2.1 \mathrm{~dB}(\mathrm{~A})$ for $\mathrm{CPCB}$, Head quarters and maximum increase in $L_{\text {night }}$ levels is $2.1 \mathrm{~dB}(\mathrm{~A})$ for the ITO area. The $L_{\text {night }}$ levels are very high as compared to the ambient noise standards for Dilshad Garden, Delhi Technological University (DTU), ITO and NSIT Dwarka sites. The ambient noise levels at ITO site are very high as compared to the ambient standards. The ambient noise levels have decreased for Dilshad garden site by $0.7 \mathrm{~dB}(\mathrm{~A})$ for $L_{\text {day }}$ and $2.1 \mathrm{~dB}(\mathrm{~A})$ for $L_{\text {night }}$ since the past four years. Also, for the DTU, Bawana site; the ambient noise levels have decreased by $0.5 \mathrm{~dB}(\mathrm{~A})$ for $L_{\text {day }}$ and $0.3 \mathrm{~dB}(\mathrm{~A})$ for $L_{\text {night }}$ since the past four years It can be observed that no site in Delhi region meets the ambient noise standards. The CPCB site marginally meets the ambient noise standards as $L_{\text {day }}$ levels are $0.9 \mathrm{~dB}(\mathrm{~A})$ higher than the recommended standards.

\subsubsection{Lucknow city}

The ambient noise levels have significantly increased in four years for the Gomti nagar area and that for PGI Hospital. The $L_{\text {day }}$ levels have increased by $8.2 \mathrm{~dB}(\mathrm{~A})$ and $L_{\text {night }}$ by $7.5 \mathrm{~dB}(\mathrm{~A})$ for Gomti nagar area since past four years. The PGI Hospital site experienced an increase in $L_{\text {day }}$ levels by $7.1 \mathrm{~dB}(\mathrm{~A})$ 


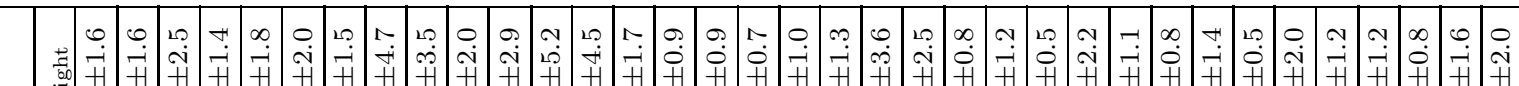

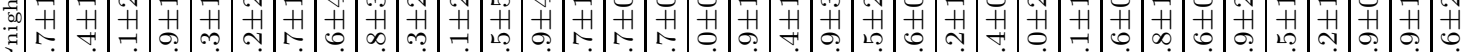
$\forall \underset{f}{A}$

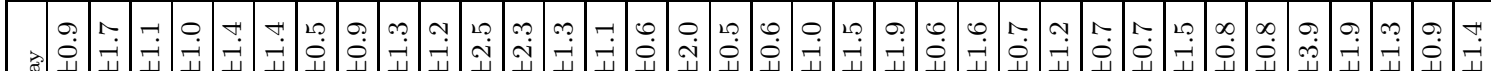

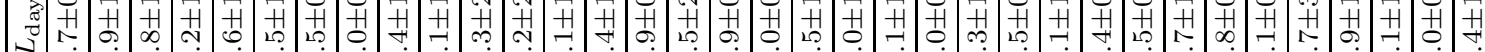

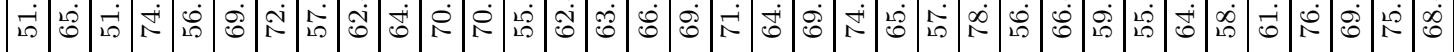

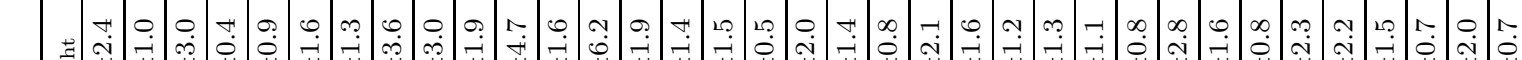

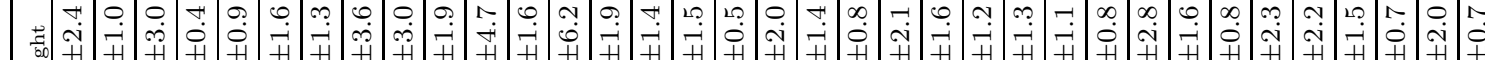

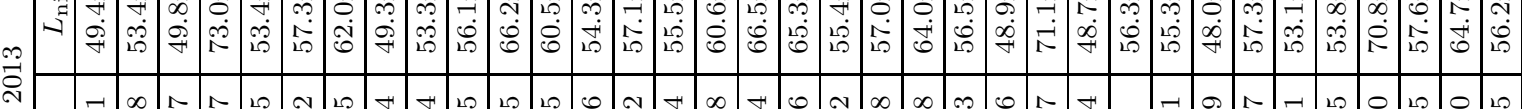

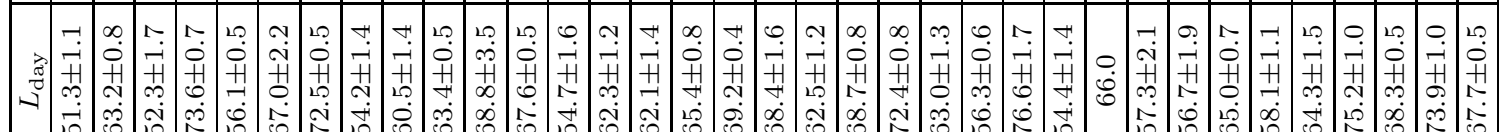

-

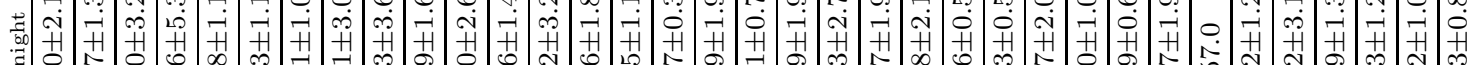

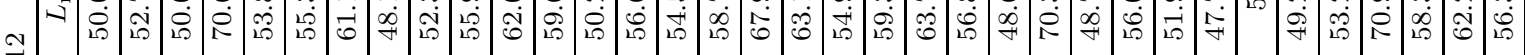
ลี่

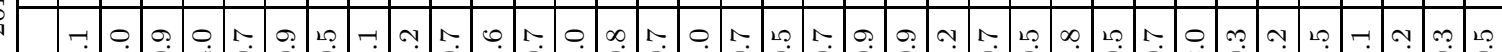
(2)

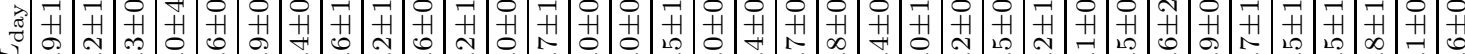
宅

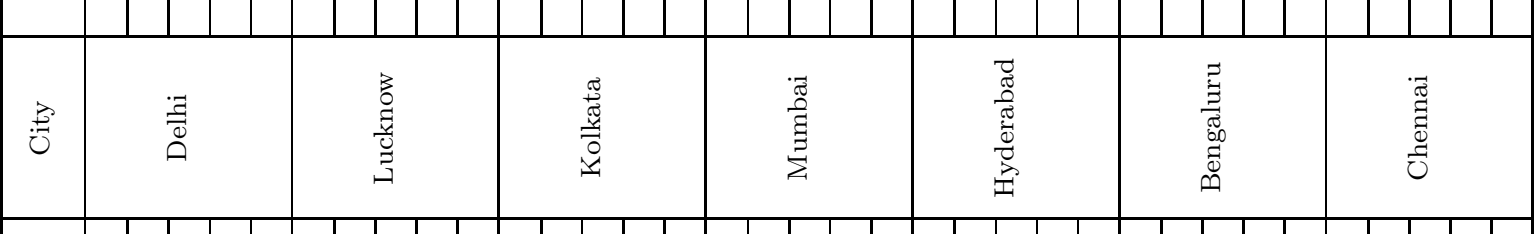

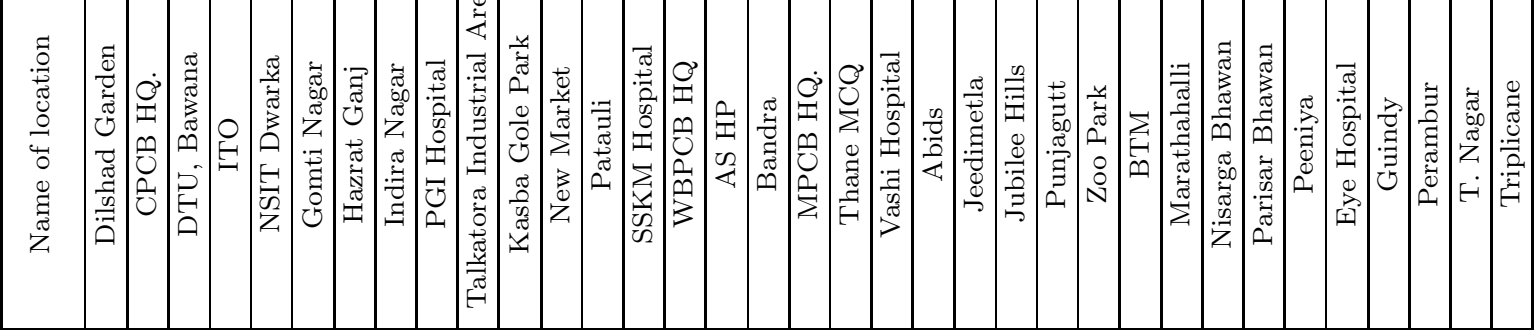


and $L_{\text {night }}$ by $6.0 \mathrm{~dB}(\mathrm{~A})$ since past four years. The night levels, $L_{\text {night }}$ at Gomti nagar, Harat Ganj and PGI Hospital are very high as compared to the ambient noise standards. It is observed that only one site (Talkatora industrial site) meets the ambient noise standards. The day equivalent level, $L_{\text {day }}$ has increased by $1.0 \mathrm{~dB}(\mathrm{~A})$, while night equivalent level, $L_{\text {night }}$ has increased by $1.6 \mathrm{~dB}(\mathrm{~A})$ in the past four years for Talkatora industrial site.

\subsubsection{Kolkata city}

The ambient noise levels have marginally increased in four years in Kolkata city except for Kasba Gole park site and New Market area, whereby the $L_{\text {day }}$ levels have increased by $6.7 \mathrm{~dB}(\mathrm{~A})$ and $L_{\text {night }}$ by $8.5 \mathrm{~dB}(\mathrm{~A})$ since the past four years for Kasba Gole park site and $L_{\text {day }}$ levels have increased by $2.9 \mathrm{~dB}(\mathrm{~A})$ and $L_{\text {night }}$ by $7.5 \mathrm{~dB}(\mathrm{~A})$ since past four years for New Market site. The night levels, $L_{\text {night }}$ at Patauli residential area, New Market and SSKM hospital area are very high as compared to the ambient noise standards. The night levels, $L_{\text {night }}$ have increased by $4.5 \mathrm{~dB}(\mathrm{~A})$ for Patauli area, $2.4 \mathrm{~dB}(\mathrm{~A})$ for SSKM hospital and $2 \mathrm{~dB}(\mathrm{~A})$ for WBPCB, head quarters since the past four years. The Kasba Gole park industrial site site meets the ambient noise standards.

\subsubsection{Mumbai city}

The ambient noise levels have marginally increased in four years in Mumbai city for all the sites under consideration except the MPCB, head quarters site. The maximum increase in $L_{\text {day }}$ value since the past four years is $4.3 \mathrm{~dB}(\mathrm{~A})$, while that for $L_{\text {night }}$ is $5.1 \mathrm{~dB}(\mathrm{~A})$ for the MPCB, head quarters site. The night levels, $L_{\text {night }}$ at Acworth Hospital (ASHP), Bandra, Maharashtra Pollution Control Board (MPCB) and Vaishi hospital are very high as compared to the ambient noise standards. No site meets the ambient noise standard out of all the sites in the city under consideration.

\subsubsection{Hyderabad city}

The ambient noise levels have marginally increased in four years in Hyderabad city for all the sites under consideration. The maximum increase in $L_{\text {day }}$ and $L_{\text {night }}$ levels since the past four years is $2.7 \mathrm{~dB}(\mathrm{~A})$ and $2.6 \mathrm{~dB}(\mathrm{~A})$ for Jeedimetla site. The Jubliee Hills residential area experienced a decrease in the ambient noise levels since the past four years. The $L_{\text {day }}$ value has decreased by $0.1 \mathrm{~dB}(\mathrm{~A})$, while $L_{\text {night }}$ has decreased by $1.5 \mathrm{~dB}(\mathrm{~A})$. The night levels, $L_{\text {night }}$ at Abids and Punjagutta area are very high as compared to the ambient standards. Only one location (Jeedimetla industrial site) meets the ambient noise standards.

\subsubsection{Bengaluru city}

The ambient noise levels have marginally increased in four years in Bengaluru city for all the sites under consideration. The maximum increase in $L_{\text {day }}$ value since the past four years is $2.6 \mathrm{~dB}(\mathrm{~A})$, while that for $L_{\text {night }}$ is $2.5 \mathrm{~dB}(\mathrm{~A})$ for Marathahalli area. Some areas like Parisar Bhawan have experienced a decrease in the ambient noise levels since the past four years. The $L_{\text {day }}$ value has decreased maximum by $1.7 \mathrm{~dB}(\mathrm{~A})$ for Parisar Bhawan, while $L_{\text {night }}$ has decreased by $1.6 \mathrm{~dB}(\mathrm{~A})$. The Nisarga Bhawan site shows a decrement in $L_{\text {day }}$ value by $2.4 \mathrm{~dB}(\mathrm{~A})$, while the $L_{\text {night }}$ levels has marginally increased by $0.4 \mathrm{~dB}(\mathrm{~A})$ in the past four years. The night levels, $L_{\text {night }}$ at BTM, Bengaluru are very high as compared to the ambient noise levels. It is observed that only one location namely, Peenya industrial site meets the ambient noise standards.

\subsubsection{Chennai city}

The ambient noise levels have marginally increased in four years in Chennai city for all the sites under consideration. The maximum increase in $L_{\text {day }}$ value since the past four years is $1.6 \mathrm{~dB}(\mathrm{~A})$, while that for $L_{\text {night }}$ is $5 \mathrm{~dB}(\mathrm{~A})$ for T. Nagar area. The $L_{\text {day }}$ value has decreased maximum by $2.3 \mathrm{~dB}(\mathrm{~A})$ for Eye hospital, while $L_{\text {night }}$ has decreased by $1.2 \mathrm{~dB}(\mathrm{~A})$ for Perambur area. The night levels, $L_{\text {night }}$ at Eye Hospital and T. Nagar are very high as compared to the ambient noise standards. No site meets the ambient noise standards of all the sites under consideration.

\subsection{Zone wise analysis}

\subsubsection{Commercial zone}

Figures 2 and 3 describe the monthly variation of day equivalent level and night equivalent level, $L_{\text {day }}$ and $L_{\text {night }}$ for commercial areas in Chennai, Lucknow, Bengaluru and Kolkata in the year 2014. These observations suggest that T. Nagar, Hazrat Ganj, Perambur and New Market requires noise abatement measures in order to bring the levels below the ambient noise standards. The day levels have increased by $4 \mathrm{~dB}(\mathrm{~A})$ in the year 2014 while comparing the January and December levels; while the night levels have considerably

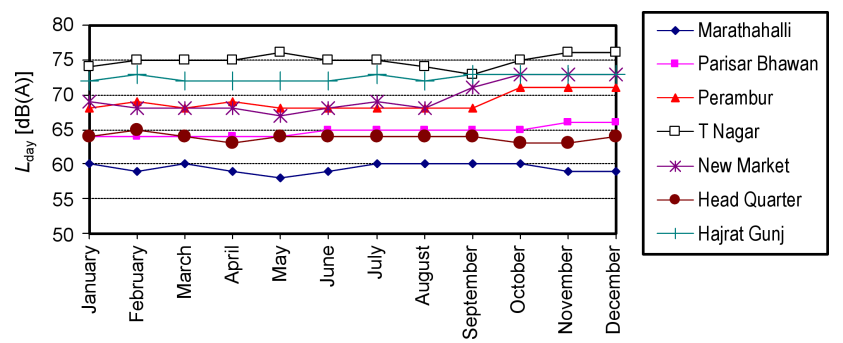

Fig. 2. Monthly variation in equivalent sound pressure level, $L_{\text {day }}$ for commercial areas in Chennai, Lucknow, Bangalore and Kolkata in year 2014. 


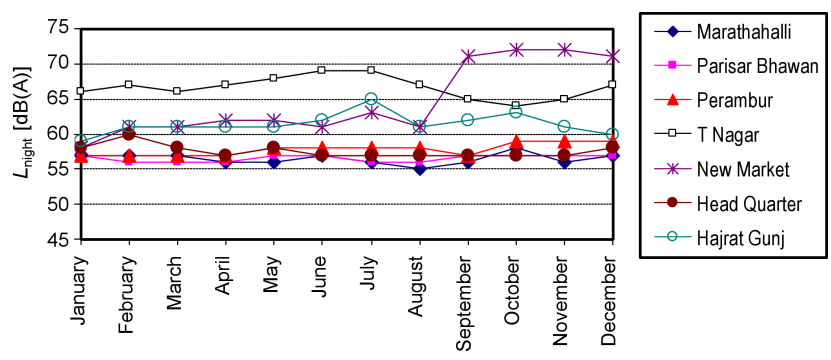

Fig. 3. Monthly variation in equivalent sound pressure level, $L_{\text {night }}$ for commercial areas in Chennai, Lucknow, Bangalore and Kolkata in year 2014.

increased by $13 \mathrm{~dB}(\mathrm{~A})$ for New Market site. Figures 4 and 5 show the monthly variation of equivalent sound level, $L_{\text {day }}$ and $L_{\text {night }}$ for commercial areas in Delhi, Mumbai and Hyderabad in the year 2014. No commercial site unlike the previous years meets the ambient noise standards as in year 2013, four sites namely CPCB site, Thane site, Marathahalli and WBPCB, head quarters site complied with the ambient stan-

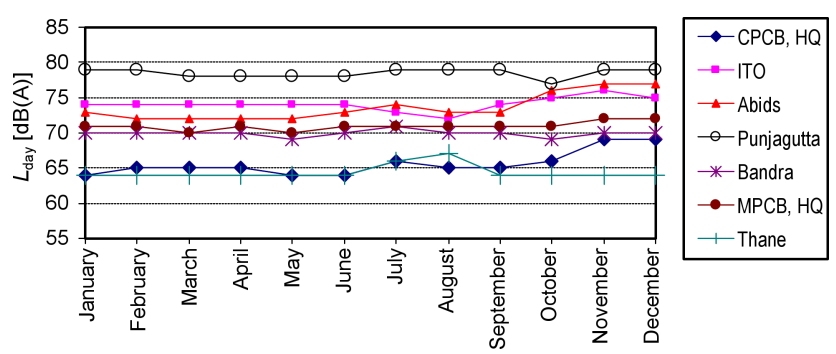

Fig. 4. Monthly variation in equivalent sound pressure level, $L_{\text {day }}$ for commercial areas in Delhi, Mumbai and Hyderabad in year 2014 .

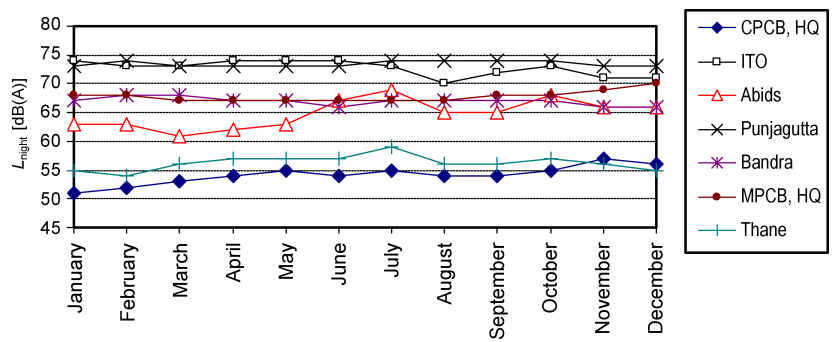

Fig. 5. Monthly variation in equivalent sound pressure level, $L_{\text {night }}$ for commercial areas in Delhi, Mumbai and Hyderabad in year 2014 . dards. The CPCB site marginally meets the ambient noise standards. The monthly variation of $\pm 5 \mathrm{~dB}(\mathrm{~A})$ for $L_{\text {day }}$ levels and $\pm 6 \mathrm{~dB}(\mathrm{~A})$ for $L_{\text {night }}$ levels is observed in case of CPCB, Headquarters and Abids area. It can be observed that ITO, Bandra, MPCB Head quarters, Abids, Punjagutta and Perambur areas also require immediate noise control measures for bringing the noise levels below the ambient noise standards. Table 3 shows the variation of $L_{\text {day }}$ and $L_{\text {night }}$ values; $L_{\text {Aeq } 24 \mathrm{~h}}$ and difference $\left(L_{\text {day }}-L_{\text {night }}\right)$ values in $\mathrm{dB}(\mathrm{A})$ for different areas in year 2014 . The $L_{\text {day }}$ levels varied from $59.5 \mathrm{~dB}(\mathrm{~A})$ for Marathahalli area to $78.5 \mathrm{~dB}(\mathrm{~A})$ for Punjagutta area, while the $L_{\text {night }}$ levels varied from $54.4 \mathrm{~dB}(\mathrm{~A})$ for $\mathrm{CPCB}$ headquarters to $73.4 \mathrm{~dB}(\mathrm{~A})$ for Punjagutta area. The average difference between $\left(L_{\text {day }}-L_{\text {night }}\right)$ is $6.5 \mathrm{~dB}(\mathrm{~A})$ as shown in Table 3 whereby the maximum difference of $11.5 \mathrm{~dB}(\mathrm{~A})$ is observed for CPCB, Head quarters and minimum difference of $1.3 \mathrm{~dB}(\mathrm{~A})$ for ITO area. The day-night average sound level varies from $63.3 \mathrm{~dB}(\mathrm{~A})$ at Marathahalli site to $80.8 \mathrm{~dB}(\mathrm{~A})$ for Punjagutta site; while the $L_{\mathrm{Aeq}, 24 \mathrm{~h}}$ ranges from $58.7 \mathrm{~dB}(\mathrm{~A})$ at Marathahalli site to $77.4 \mathrm{~dB}(\mathrm{~A})$ for Punjagutta site.

\subsubsection{Industrial zone}

Figures 6 and 7 describe the monthly variation of day equivalent level and night equivalent level, $L_{\text {day }}$ and $L_{\text {night }}$ in the year 2014 for all the industrial sites under consideration. It can be observed from the $L_{\text {day }}$ levels that the Guindy site requires immediate noise control measures. The Peeniya industrial site and Jeedimetla site has the ambient noise levels well within the ambient noise standards. The monthly variation of $L_{\text {day }}$ and $L_{\text {night }}$ is not so high except in

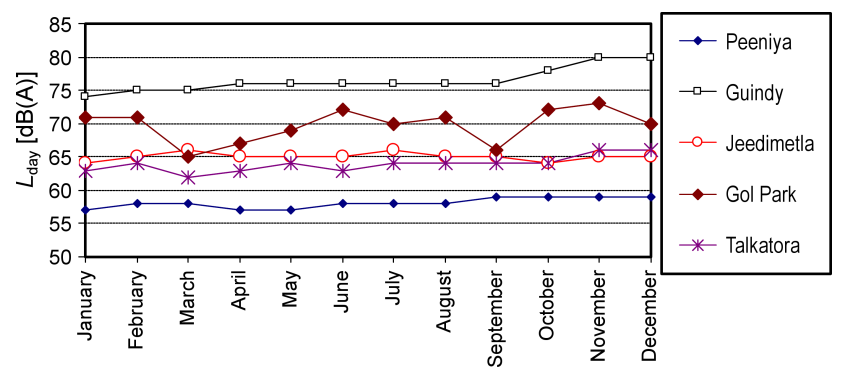

Fig. 6. Monthly variation in equivalent sound pressure level, $L_{\text {day }}$ for industrial areas in seven cities in year 2014 .

Table 3. Variation of $L_{\text {day }}$ and $L_{\text {night }}$ values; $L_{\text {Aeq }, 24 \mathrm{~h}}$ and difference $\left(L_{\text {day }}-L_{\text {night }}\right)$ values in dB(A) for different areas/zone in year 2014.

\begin{tabular}{|c|c|c|c|c|c|c|c|c|c|c|c|}
\hline \multirow{2}{*}{$\begin{array}{c}\text { Category } \\
\text { of area/zone }\end{array}$} & \multicolumn{2}{|c|}{$L_{\text {day }}$} & \multicolumn{2}{|c|}{$L_{\text {night }}$} & \multicolumn{3}{|c|}{$\left(L_{\text {day }}-L_{\text {night }}\right)$} & \multicolumn{2}{|c|}{$L_{\text {Aeq, } 24 \mathrm{~h}}$} & \multicolumn{2}{|c|}{$L_{\mathrm{dn}}$} \\
\hline & Min & Max & Min & $\operatorname{Max}$ & Min & Average & Max & Min & $\operatorname{Max}$ & Min & $\operatorname{Max}$ \\
\hline Industrial area & 58.1 & 76.9 & 54.9 & 72.2 & 2.2 & 4.7 & 6.80 & 57.3 & 75.8 & 61.6 & 79.4 \\
\hline Commercial area & 59.5 & 78.5 & 54.4 & 73.4 & 1.3 & 6.5 & 11.5 & 58.7 & 77.4 & 63.3 & 80.8 \\
\hline Residential area & 55.1 & 69.5 & 48.8 & 61.2 & 1.2 & 7.3 & 10.8 & 54.4 & 68.0 & 57.0 & 70.1 \\
\hline Silence zone & 51.7 & 69.0 & 48.7 & 60.9 & 2.7 & 5.4 & 8.20 & 50.9 & 67.6 & 55.4 & 69.7 \\
\hline
\end{tabular}




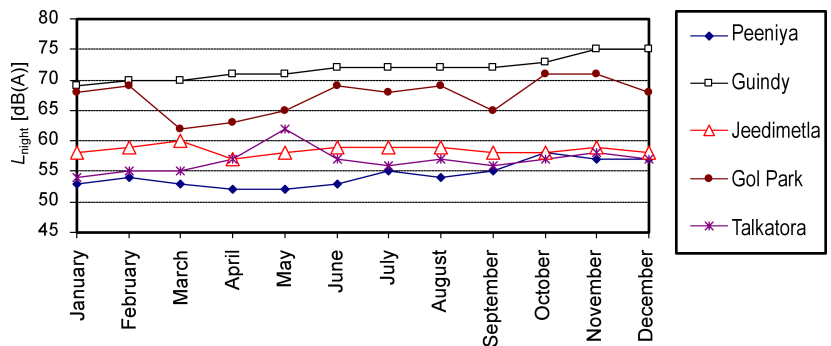

Fig. 7. Monthly variation in equivalent sound pressure level, $L_{\text {night }}$ for industrial areas in seven cities in year 2014 .

case of Gol Park area and Guindy site. The $L_{\text {day }}$ levels varied from $58.1 \mathrm{~dB}(\mathrm{~A})$ for Peenya site to $76.9 \mathrm{~dB}(\mathrm{~A})$ for Guindy site, while the $L_{\text {night }}$ levels varies from $54.9 \mathrm{~dB}(\mathrm{~A})$ for Peenya site to $72.2 \mathrm{~dB}(\mathrm{~A})$ for Guindy area. Four sites out of the five sites meets the ambient noise standards, whereby the Guindy site requires immediate noise control measures. The average difference between $\left(L_{\text {day }}-L_{\text {night }}\right)$ is $4.7 \mathrm{~dB}(\mathrm{~A})$, whereby the maximum difference of $6.8 \mathrm{~dB}(\mathrm{~A})$ is observed for Talkatora area and minimum difference of $2.2 \mathrm{~dB}(\mathrm{~A})$ for Kasba gole site. The day-night average sound level varies from $61.6 \mathrm{~dB}(\mathrm{~A})$ at Peeniya site to $79.4 \mathrm{~dB}(\mathrm{~A})$ for Guindy site; while the $L_{\mathrm{Aeq}, 24 \mathrm{~h}}$ ranges from $57.3 \mathrm{~dB}(\mathrm{~A})$ at Peeniya site to $75.8 \mathrm{~dB}(\mathrm{~A})$ for Guindy site.

\subsubsection{Residential zone}

Figures 8 and 9 describe the monthly variation of day equivalent level and night equivalent level, $L_{\text {day }}$ and $L_{\text {night }}$ in the year 2014 for residential sites under consideration. It can be observed that for Triplicane, BTM and Gomti nagar area, there is an immediate

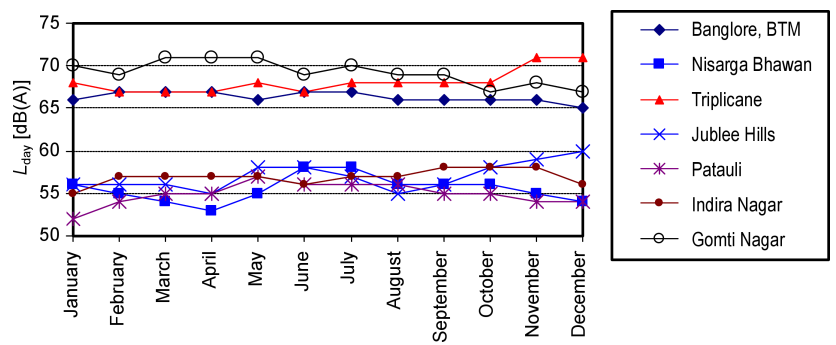

Fig. 8. Monthly variation in equivalent sound pressure level, $L_{\text {day }}$ for residential areas in seven cities in year 2014 .

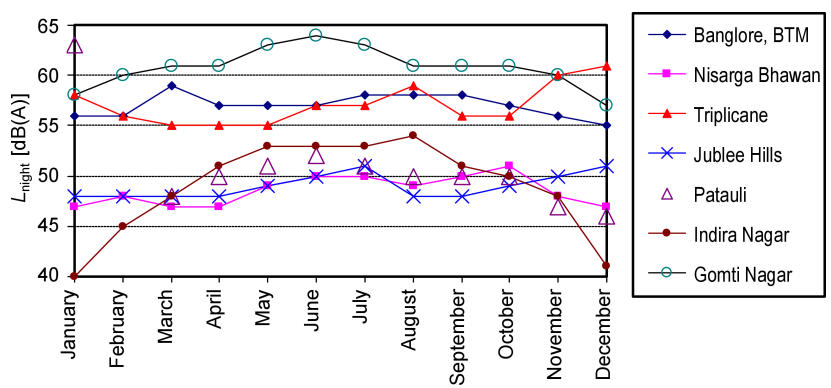

Fig. 9. Monthly variation in equivalent sound pressure level, $L_{\text {night }}$ for residential areas in seven cities in year 2014 . requirement of noise control measures. The monthly variation of $L_{\text {night }}$ values for Triplicane, Gomti nagar and Indira nagar is very high. The Patauli site experienced an $L_{\text {night }}$ value of $63 \mathrm{~dB}(\mathrm{~A})$ for January, 2014, while for the rest of months of the year; the levels is $\leq 52 \mathrm{~dB}(\mathrm{~A})$. The $L_{\text {day }}$ levels varied from $55.1 \mathrm{~dB}(\mathrm{~A})$ for Patauli area to $69.5 \mathrm{~dB}(\mathrm{~A})$ for Gomti nagar, while the $L_{\text {night }}$ levels varied from $48.8 \mathrm{~dB}(\mathrm{~A})$ for Nisarga bhawan to $61.2 \mathrm{~dB}(\mathrm{~A})$ for Gomti nagar. Out of seven residential sites, no site meets the ambient noise standards. The average difference between $\left(L_{\text {day }}-L_{\text {night }}\right)$ is observed to be $7.3 \mathrm{~dB}(\mathrm{~A})$; whereby the maximum difference of $10.8 \mathrm{~dB}(\mathrm{~A})$ is observed for Triplicane area and $1.2 \mathrm{~dB}(\mathrm{~A})$ for Patauli area (Table 3). The daynight average sound level varies from $57.0 \mathrm{~dB}(\mathrm{~A})$ for Nisarga bhawan site to $70.1 \mathrm{~dB}(\mathrm{~A})$ for Gomti nagar site; while the $L_{\mathrm{Aeq}, 24 \mathrm{~h}}$ ranges from $54.4 \mathrm{~dB}(\mathrm{~A})$ for Nisarga bhawan site to $68.0 \mathrm{~dB}(\mathrm{~A})$ for Gomti nagar site.

\subsubsection{Silence zone}

Figures 10 and 11 describe the monthly variation of day equivalent level and night equivalent level, $L_{\text {day }}$ and $L_{\text {night }}$ in the year 2014 for sites under consideration lying in silence zone. It can be observed that Eye hospital, SSKM hospital, Vaishi hospital and Acworth hospital have high ambient levels as compared to the standards and thus require immediate noise control measures. The monthly variation of $L_{\text {day }}$ at Eye hospital is high and that of $L_{\text {night }}$ for PGI, Dilshad garden, DTU, Bawana and Vashi hospital is very high. For the

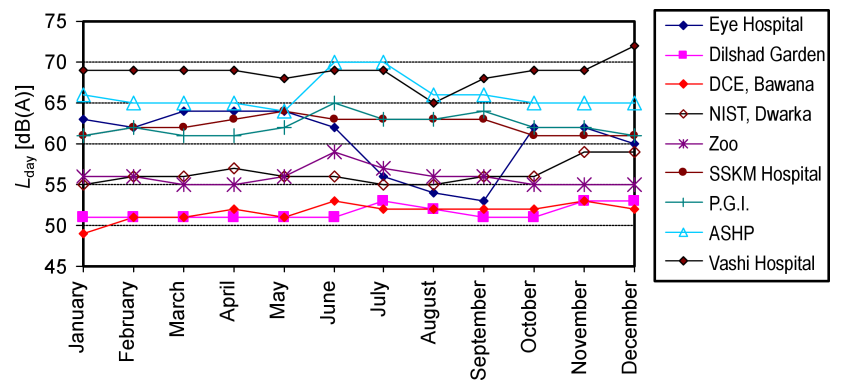

Fig. 10. Monthly variation in equivalent sound pressure level, $L_{\text {day }}$ for areas lying under silence zone across seven cities in year 2014.

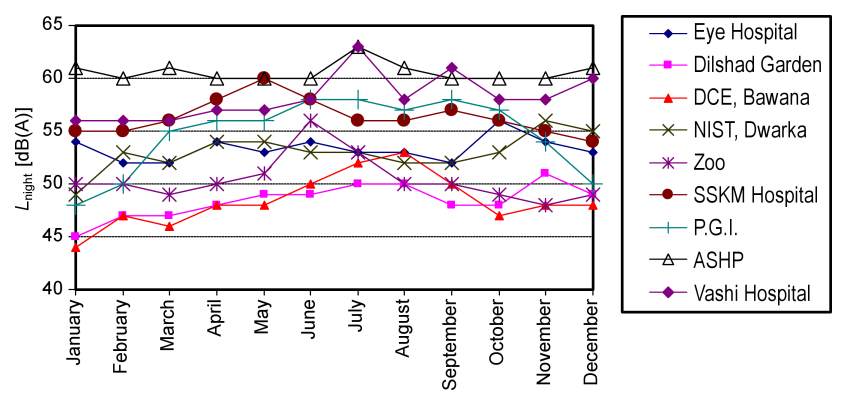

Fig. 11. Monthly variation in equivalent sound pressure level, $L_{\text {night }}$ for areas lying under silence zone across seven cities in year 2014 . 
DTU, Bawana site, the monthly variation in $L_{\text {night }}$ is up to $9 \mathrm{~dB}(\mathrm{~A})$. The $L_{\text {day }}$ levels varied from $51.7 \mathrm{~dB}(\mathrm{~A})$ for Dilshad garden to $69.0 \mathrm{~dB}(\mathrm{~A})$ for Vashi hospital, while the $L_{\text {night }}$ levels varied from $48.7 \mathrm{~dB}(\mathrm{~A})$ for Dilshad garden to $60.9 \mathrm{~dB}(\mathrm{~A})$ for Vashi hospital. The average difference between $\left(L_{\text {day }}-L_{\text {night }}\right)$ is observed to be $5.4 \mathrm{~dB}(\mathrm{~A})$, whereby the maximum difference of $8.2 \mathrm{~dB}(\mathrm{~A})$ is observed for Eye hospital and minimum difference of $2.7 \mathrm{~dB}(\mathrm{~A})$ for DTU, Bawana site. The day-night average sound level varies from $55.4 \mathrm{~dB}(\mathrm{~A})$ at Dilshad garden site to $69.7 \mathrm{~dB}(\mathrm{~A})$ for Vashi hospital site; while the $L_{\mathrm{Aeq}, 24 \mathrm{~h}}$ ranges from $50.9 \mathrm{~dB}(\mathrm{~A})$ at Dilshad garden site to $67.6 \mathrm{~dB}(\mathrm{~A})$ for Vashi hospital site.

\section{Overall noise pollution scenario}

The $L_{\text {day }}$ and $L_{\text {night }}$ levels observed for 35 sites for the year 2014 reveals that only 4 industrial sites $(11.4 \%)$ meet the ambient noise standards. The CPCB, head quarters site marginally meets the ambient noise standards. The situation is quite alarming as in the past two years 2012 and 2013, 9 sites including 4 commercial and 5 industrial sites meet the ambient nose standards. It is observed from the year 2011 noise monitoring data that 8 sites including 4 commercial and 4 industrial meet the ambient noise standards. The 4 commercial sites that complied with the ambient noise standards were CPCB, headquarters; West Bengal headquarters; Thane MCQ and Marathahalli. However, the annual average ambient levels observed for the year 2014 reveals that $L_{\text {night }}$ levels for West Bengal WBPCB headquarters; Thane MCQ and Marathahalli are very high as compared to the ambient standards. Table 4 shows the frequency distribution of $L_{\text {day }}$ and $L_{\text {night }}$; $L_{\mathrm{dn}}$ and $L_{\mathrm{Aeq}, 24 \mathrm{~h}}$ in $\mathrm{dB}(\mathrm{A})$ for seven major cities (35 sites) in the year 2014. It can be observed that 13 sites $(37.1 \%)$ experienced $L_{\text {night }}$ levels more than $60 \mathrm{~dB}(\mathrm{~A})$, while 25 sites $(71.4 \%)$ experienced $L_{\text {day }}$ levels more than $60 \mathrm{~dB}(\mathrm{~A})$. It can be also observed from Table 4 that 22 sites $(62.9 \%)$ experienced $L_{\mathrm{dn}}$ levels $>65 \mathrm{~dB}(\mathrm{~A})$, while 15 sites $(42.9 \%)$ experienced $L_{\mathrm{Aeq}, 24 \mathrm{~h}}$ levels $>65 \mathrm{~dB}(\mathrm{~A})$. Figure 12 shows the $L_{\text {Aeq,24h }}$ levels for all the 35 sites under consideration for past four years. It is observed that $L_{\mathrm{Aeq}, 24 \mathrm{~h}}$ levels ranges from $50.9 \mathrm{~dB}(\mathrm{~A})$ for Dilshad garden site to $77.4 \mathrm{~dB}(\mathrm{~A})$ for Punjagutta commercial area. The U.S Department of Housing and Urban Development (HUD) recommends the $L_{\mathrm{Aeq}} \leq 49 \mathrm{~dB}(\mathrm{~A})$ as clearly acceptable; $49<L_{\text {Aeq }} \leq 62 \mathrm{~dB}(\mathrm{~A})$ as normally acceptable, $62<L_{\text {Aeq }} \leq 76 \mathrm{~dB}(\mathrm{~A})$ as normally unacceptable and $L_{\mathrm{Aeq}}>76 \mathrm{~dB}(\mathrm{~A})$ as clearly unacceptable (U.S Department of Housing and Urban Development, 1984; OLAYINKA et al., 2013). It can be observed from Fig. 12 that 13 sites (37.1\%) have $L_{\mathrm{Aeq}, 24 \mathrm{~h}}$ levels between 49 and $62 \mathrm{~dB}(\mathrm{~A})$ and thus is classified as normally acceptable, while 21 sites $(60 \%)$ are normally unacceptable as $L_{\text {Aeq,24h }}$ levels range between 62 and $76 \mathrm{~dB}(\mathrm{~A})$. The Punjagutta site experienced $L_{\text {Aeq,24h }}$ levels of $77.4 \mathrm{~dB}(\mathrm{~A})$, which is clearly unacceptable. Figure 13 shows the day-night average sound levels, $L_{\mathrm{dn}}$ for all the 35 sites under consideration for past four years. The $L_{\mathrm{dn}}$ levels ranges from $55.4 \mathrm{~dB}(\mathrm{~A})$ for Dilshad Garden site to $80.8 \mathrm{~dB}(\mathrm{~A})$ for Punjagutta commercial area. It can be observed that 13 sites $(37.1 \%)$ have $L_{\text {dn }}$ levels less than $65 \mathrm{~dB}(\mathrm{~A})$ and are classified as acceptable; while 18 sites $(51.4 \%)$ have levels between 65 to $75 \mathrm{~dB}(\mathrm{~A})$ and are classified as normally unacceptable. Four sites namely, ITO, Punjagutta, Guindy and T. Nagar have $L_{\mathrm{dn}}$ levels above $75 \mathrm{~dB}(\mathrm{~A})$ and are classified as unacceptable as per HUD criteria (U.S. Department of Housing and Urban Development, 1984). The recent study on proposed amendments in ambient noise standards of India based on single-noise descriptor proposes $L_{\mathrm{Aeq}, 24 \mathrm{~h}}$ of $70 \mathrm{~dB}(\mathrm{~A})$ for industrial zone; $65 \mathrm{~dB} L_{\mathrm{Aeq}, 24 \mathrm{~h}}$ for commercial area and mixed residential and commercial zones; $60 \mathrm{~dB}(\mathrm{~A})$ for residen-

Table 4. Frequency distribution of $L_{\text {day }}$ and $L_{\mathrm{night}} ; L_{\mathrm{dn}}$ and $L_{\mathrm{Aeq}, 24 \mathrm{~h}}$ in $\mathrm{dB}(\mathrm{A})$ for seven major cities (35 sites) in year 2014 .

\begin{tabular}{|c|c|c|c|c|c|c|c|c|}
\hline \multirow{2}{*}{$\begin{array}{c}\text { Variation } \\
\text { of parameters, } \\
L_{\text {day }}, L_{\text {night }} \text { and } L_{\mathrm{dn}} \\
{[\mathrm{dB}(\mathrm{A})]}\end{array}$} & \multicolumn{2}{|c|}{$L_{\text {day }}$} & \multicolumn{2}{|c|}{$L_{\text {night }}$} & \multicolumn{2}{|c|}{$L_{\mathrm{dn}}$} & \multicolumn{2}{|c|}{$L_{\text {Aeq }, 24 \mathrm{~h}}$} \\
\hline & $\begin{array}{c}\text { No } \\
\text { of sites }\end{array}$ & $\begin{array}{c}\text { Percentage } \\
\text { of noise } \\
\text { monitoring } \\
\text { locations }\end{array}$ & $\begin{array}{c}\text { No } \\
\text { of sites }\end{array}$ & $\begin{array}{c}\text { Percentage } \\
\text { of noise } \\
\text { monitoring } \\
\text { locations }\end{array}$ & $\begin{array}{c}\text { No } \\
\text { of sites }\end{array}$ & $\begin{array}{c}\text { Percentage } \\
\text { of noise } \\
\text { monitoring } \\
\text { locations }\end{array}$ & $\begin{array}{c}\text { No } \\
\text { of sites }\end{array}$ & $\begin{array}{c}\text { Percentage } \\
\text { of noise } \\
\text { monitoring } \\
\text { locations }\end{array}$ \\
\hline $45<L_{\mathrm{eq}} \leq 50$ & 0 & 0 & 4 & 11.4 & 0 & 0 & 0 & 0 \\
\hline $50<L_{\mathrm{eq}} \leq 55$ & 2 & 5.7 & 7 & 20.0 & 0 & 0 & 5 & 14.3 \\
\hline $55<L_{\mathrm{eq}} \leq 60$ & 8 & 22.9 & 11 & 31.4 & 6 & 17.1 & 5 & 14.3 \\
\hline $60<L_{\mathrm{eq}} \leq 65$ & 8 & 22.9 & 4 & 11.4 & 7 & 20.2 & 10 & 28.6 \\
\hline $65<L_{\mathrm{eq}} \leq 70$ & 8 & 22.9 & 6 & 17.1 & 11 & 31.4 & 8 & 22.9 \\
\hline $70<L_{\mathrm{eq}} \leq 75$ & 7 & 20.0 & 3 & 8.6 & 7 & 20.0 & 5 & 14.3 \\
\hline $75<L_{\mathrm{eq}} \leq 80$ & 2 & 5.7 & 0 & 0 & 3 & 8.6 & 2 & 5.7 \\
\hline $80<L_{\mathrm{eq}} \leq 85$ & 0 & 0 & 0 & 0 & 1 & 2.9 & 0 & 0 \\
\hline
\end{tabular}




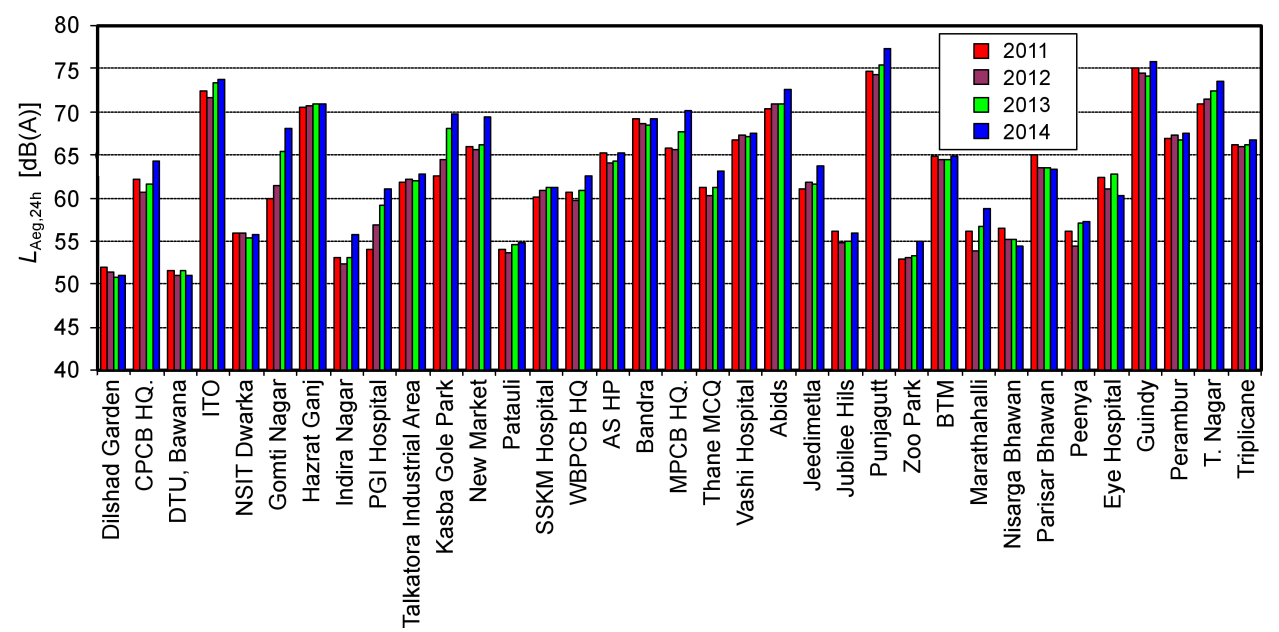

Fig. 12. $L_{\mathrm{Aeq}, 24 \mathrm{~h}}$ at 35 locations spread across seven major cities all over India in year 2011-2014.

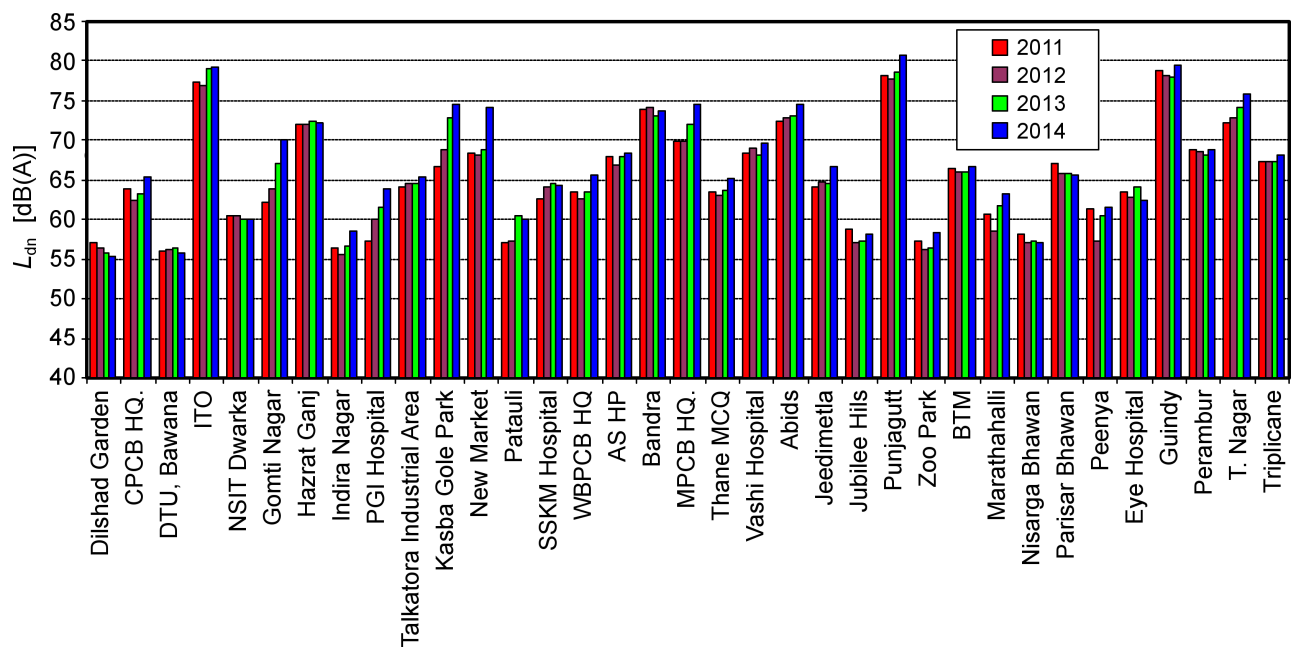

Fig. 13. $L_{\mathrm{dn}}$ at 35 locations spread across seven major cities all over India in year 2011-2014.

tial zone and $55 \mathrm{~dB}(\mathrm{~A})$ for silence zone (GARG et al., 2015d). In accordance with these criteria; 16 sites out of 35 sites (45.7\%); 17 sites (48.6\%) in 2013; 16 sites in 2012 and 18 sites in 2011 meets the ambient noise standards. The lowest observed adverse effect level (LOAEL) of night noise, $40 \mathrm{~dB} L_{\text {night }}$ can be considered a health-based limit value of the night noise guidelines (NNG) necessary to protect from adverse health effects of noise. An interim target of $55 \mathrm{~dB} L_{\text {night }}$ is recommended in the situation wherein the achievement of NNG is not feasible (WHO report, 2009; KIM, BERG, 2010). Thus, considering the target of $55 \mathrm{~dB} L_{\text {night }}$, 11 locations meets the criteria for the year 2014 noise monitoring data. These observations thus suggest the need for a review of ambient noise standards in India especially for the residential and silence zones as relatively higher limits imposed for residential and areas under silence zones, but strictly enforced can be a great step in controlling the ambient noise levels and reducing the health hazards associated with noise pollution.
Figure 14 shows the $\left(L_{\text {day }}-L_{\text {night }}\right)$ in $\mathrm{dB}$ at 35 locations spread across seven major cities all over India in the year 2014. The lowest value of $1.2 \mathrm{~dB}(\mathrm{~A})$ is observed for Patauli area, while the highest value of $11.5 \mathrm{~dB}(\mathrm{~A})$ is observed for $\mathrm{CPCB}$, Head quarters site. The past two years annual average $L_{\text {day }}$ and $L_{\text {night }}$ levels reveal that the minimum value of $\left(L_{\text {day }}-L_{\text {night }}\right)$ of $0.4 \mathrm{~dB}(\mathrm{~A})$ for Patauli area (in the year 2013) and 1.1 for Bandra site (in the year 2012) was observed. The maximum difference of annual average $L_{\text {day }}$ and $L_{\text {night }}$ levels was observed for Vashi hospital (in the year 2013) and $11.3 \mathrm{~dB}(\mathrm{~A})$ for Hazrat Ganj and Triplicane area. Table 5 shows frequency distribution of difference $\left(L_{\text {day }}-L_{\text {night }}\right)$ values in $\mathrm{dB}(\mathrm{A})$ for all 35 sites in the past four years. The $\left(L_{\text {day }}-L_{\text {night }}\right)$ value for Bandra site in the year 2014 was $2.9 \mathrm{~dB}(\mathrm{~A})$. The analysis of $\left(L_{\text {day }}-L_{\text {night }}\right)$ for the year 2014 ambient noise levels shows that $11.4 \%$ of the observations show a difference $\geq 10 \mathrm{~dB}(\mathrm{~A}), 54.3 \%$ of observations show a difference between 5 to $10 \mathrm{~dB}(\mathrm{~A})$ and 


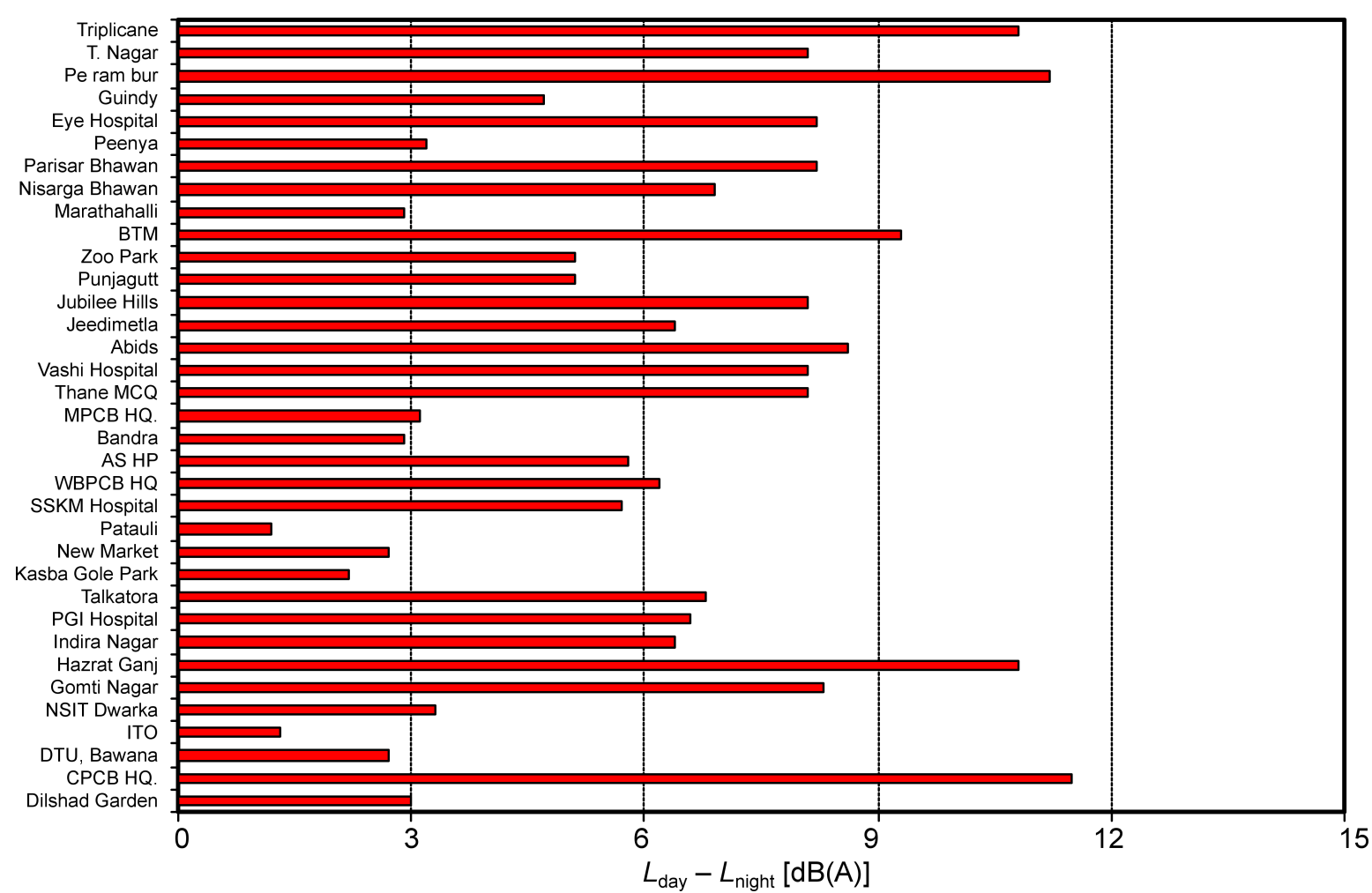

Fig. 14. $\left(L_{\text {day }}-L_{\text {night }}\right)$ in dB at 35 locations spread across seven major cities all over India in year 2014 .

Table 5. Frequency distribution of difference $\left(L_{\text {day }}-L_{\text {night }}\right)$ values in $\mathrm{dB}(\mathrm{A})$ for all 35 sites in past four years.

\begin{tabular}{|c|c|c|c|c|c|c|c|c|}
\hline $\begin{array}{c}\text { Variation } \\
\text { of difference } \\
\left(L_{\text {day }}-L_{\text {night }}\right) \\
\text { values }[\mathrm{dB}(\mathrm{A})]\end{array}$ & $\begin{array}{c}\text { No } \\
\text { of sites }\end{array}$ & $\begin{array}{c}\text { Percentage } \\
\text { of noise } \\
\text { monitoring } \\
\text { locations }\end{array}$ & $\begin{array}{c}\text { No } \\
\text { of sites }\end{array}$ & $\begin{array}{c}\text { Percentage } \\
\text { of noise } \\
\text { monitoring } \\
\text { locations }\end{array}$ & $\begin{array}{c}\text { No } \\
\text { of sites }\end{array}$ & $\begin{array}{c}\text { Percentage } \\
\text { of noise } \\
\text { monitoring } \\
\text { locations }\end{array}$ & $\begin{array}{c}\text { No } \\
\text { of sites }\end{array}$ & $\begin{array}{c}\text { Percentage } \\
\text { of noise } \\
\text { monitoring } \\
\text { locations }\end{array}$ \\
\hline $0<\left(L_{\text {day }}-L_{\text {night }}\right) \leq 5$ & 12 & $34.3 \%$ & 11 & $31.4 \%$ & 12 & $34.3 \%$ & 12 & $34.3 \%$ \\
\hline $5<\left(L_{\text {day }}-L_{\text {night }}\right) \leq 10$ & 19 & $54.3 \%$ & 19 & $54.3 \%$ & 18 & $51.4 \%$ & 19 & $54.3 \%$ \\
\hline $10<\left(L_{\text {day }}-L_{\text {night }}\right) \leq 15$ & 4 & $11.4 \%$ & 5 & $14.3 \%$ & 5 & $14.3 \%$ & 4 & $11.4 \%$ \\
\hline
\end{tabular}

$34.3 \%$ of the observations show a difference less than $5 \mathrm{~dB}(\mathrm{~A})$. The analysis of $\left(L_{\text {day }}-L_{\text {night }}\right)$ levels for past four years shows that $12.9 \%$ of the observations show a difference $\geq 10 \mathrm{~dB}(\mathrm{~A}), 53.6 \%$ of observations show a difference between 5 to $10 \mathrm{~dB}(\mathrm{~A})$ and $33.5 \%$ of the observations show a difference less than $5 \mathrm{~dB}(\mathrm{~A})$. This implies that $10 \mathrm{~dB}$ night time adjustment in day-night average sound level, $L_{\mathrm{dn}}$ to account for the increased sensitivity of noise at night, the expectation that the night time noise will be lower than during the day and for disturbance sleep protection is not appropriate in such a scenario.

The high ambient noise levels at many sites are attributed to road traffic noise. The recent study reported by MANDAL and BANDYOPADHYAY (2014) reveals that environmental pollution in developing countries of the world was due to the fast growth rate of automobile technologies coupled with the slow adaptabil- ity of upgraded technology and other socioeconomic factors. Thus, it is essential in Indian scenario to control the noisy spots especially those located in residential areas and in silence zones. Installation of noise barriers (GARG et al., 2012; 2015e; KUMAR et al., 2014), planting vegetation and earth barriers (TYAGI et al., 2006; 2013), increasing sound insulation of facades (AMUNDSEN et al., 2011; GARG et al., 2013, 2014b; RAsmussen, 2010), using double glazing's of high sound insulation (GARG et al., 2011; 2014a), using porous elastic road surfaces (WATTS et al., 1999; MeIARASHi et al., 1996), traffic and speed reductions (Murphy et al., 2011). However, all these measures when combined shall be instrumental in bringing the noise levels well below the ambient noise standards. Consequently, a comprehensive noise abatement programme considering all the Best Practicable and Economical Options (BPEOs) shall be helpful in control- 
ling the noise pollution at these sites (GARG et al., 2012; GARG, MAJI, 2016; LEE et al., 2008; MoHANAN et al., 2010).

\section{Conclusions and recommendations}

The paper describes the noise monitoring data available from the pilot project on the establishment of National Ambient Noise Monitoring Network $(N A N M N)$ across seven major cities in India for continuous noise monitoring throughout the year. The annual average $L_{\text {day }}(06-22 \mathrm{~h})$ and $L_{\text {night }}(22-06 \mathrm{~h})$ values observed in the year 2011-2014 for the 35 locations under study in which 14 locations are in commercial zone, 5 in Industrial, 7 in residential and 9 in silence zones are described. The long-term noise monitoring shows that ambient noise levels have marginally increased since the past four years for 29 sites $(82.9 \%)$ out of 35 sites under consideration. The $L_{\text {day }}$ and $L_{\text {night }}$ levels observed for 35 sites for the year 2014 reveals that only 4 industrial sites (11.4\%) meet the ambient noise standards. The analysis of $\left(L_{\text {day }}-L_{\text {night }}\right)$ for all the zones in past four years (2011-2014) reveals that $53.6 \%$ of observations show a difference between 5 to $10 \mathrm{~dB}(\mathrm{~A})$ and $33.5 \%$ observations show a difference less than or equal to $5 \mathrm{~dB}(\mathrm{~A})$, which implies that $10 \mathrm{~dB}$ night time adjustment in day-night average sound level, $L_{\mathrm{dn}}$ to account for the increased sensitivity of noise at night, the expectation that the night time noise will be lower than during the day and for disturbance sleep protection is not appropriate in such a scenario. Thus, it is imperative to adopt a comprehensive noise abatement strategy for controlling the noise pollution at these sites and bringing the ambient levels particularly the night noise levels, $L_{\text {night }}$ below the ambient noise standards as 13 sites $(37.1 \%)$ experienced $L_{\text {night }}$ levels more than $60 \mathrm{~dB}(\mathrm{~A})$. The day equivalent levels, $L_{\text {day }}$ were higher than $65 \mathrm{~dB}(\mathrm{~A})$ for the 17 sites (48.6\%). 11 locations meets the criteria of less than or equal to $55 \mathrm{~dB} L_{\text {night }}$ levels for the year 2014 noise monitoring data. In accordance with U.S Department of Housing and Urban Development (HUD), it can be observed that 13 sites

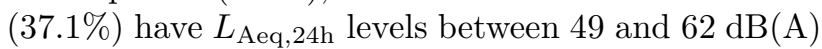
and thus is classified as normally acceptable. These observations thus suggest a review of ambient noise standards and implementing suitable amendments in them particularly for areas under silence and residential zones so as to enforce effectively the legal policy for controlling the noise pollution levels in India.

Thus, suitable noise abatement measures like ban on pressure horns of vehicles, installation of noise barriers around hospitals and schools; extensive plantation of trees, vegetation and earth berms; noise monitoring and control of loudspeakers, generator sets; enforcement of type approval testing legislations for vehicles in respect of noise, planning roadways especially for the new projects, use of porous elastic road surfaces, timing traffic lights and restricted entry of heavy vehicles in residential areas and silence zones should be undertaken to bring the ambient noise levels well below the standards. The strengthening of National Ambient Noise Monitoring Network $(N A N M N)$ in this regard to 35 more stations in same seven metropolitan cities since November, 2014 shall be indispensable in analyzing a wider noise scenario situation in the country and adoption of noise abatement measures for controlling the noise pollution in India. Further widening of $N A N M N$ network to other cities of India, noise mapping of cities similar to that established in European Directives 2002/49/EC, formulation and implementation of noise abatement goal on similar lines as recommended in Dutch noise abatement goal (NIJLAND et al., 2003) shall be indispensable in reducing the ambient noise levels. Future studies focussed on noise induced health effects, annoyance and health effects caused due to high ambient noise levels and noise maps generated for various metropolitan cities of India shall be helpful in ascertaining the environmental noise impact assessment in respect of noise and controlling the noise pollution in India.

\section{Acknowledgments}

The authors are very thankful to the CPCB authorities for their permission to publish the present work. Authors also express their gratitude towards Director, CSIR-National Physical Laboratory, India and Head, Physico-Mechanical Standards for their constant encouragement and support for the research work and allowing to publish the study. The present work is an extension to the previous work reported on the pilot project of establishment of $N A N M N$ project by CPCB, India and reports the noise levels acquired at 35 sites for the year 2014. The study was funded by CPCB, India and Ministry of Environment and Forests (MoEF), India.

\section{References}

1. Abbaspour M., Karimi E., Nassiri P., MonazZAM M.R., TAghavi L. (2015), Hierarchal assessment of noise pollution in urban areas - A case study, Transportation Research Part D, 34, 95-103.

2. Amundsen A.H., Klæboe R., Aasvang G.M. (2011), The Norwegian facade insulation study: the efficacy of facade sound insulation in reducing noise annoyance due to road traffic, Journal of Acoustical society of America, 129, 1381-1389.

3. BABISCH W. (2008), Road traffic noise and cardiovascular risk, Noise Health, 10, 38, 27-33.

4. Babisch W., Beule B., Schust M., Kersten N., IsING H. (2005), Traffic noise and risk of myocardial infarction, Epidemiology, 16, 1, 33-40. 
5. BanerJee D., Chakraborty S.K., BhattacharyyA S., Gangopadhyay A. (2008), Evaluation and analysis of road traffic noise in Asansol: An industrial town of Eastern India, International Journal of Environmental Research and Public Health, 5, 3, 165-171.

6. Basner M., Babisch W., Davis A., Brink M., Clark C., Janssen S., Stansfeld S. (2014), $A u$ ditory and non-auditory effects of noise on health, Lancet, 383, 1325-1332.

7. Cai M., Zou J., XIE J., Ma X. (2015), Road traffic noise mapping in Guangzhou using GIS and GPS, Applied Acoustics, 87, 94-102.

8. Central Pollution Control Board, Annual Report, 20112012, http://cpcb.nic.in/upload/AnnualReports/AnnualReport_43_AR_2011-12_English.pdf [access on 02.03.2016].

9. Chakrabarty S.K., BanerJee D. (2006), Monthly variation in night time noise levels at residential areas of Asansol city (India), Journalof Environmental Science and Engineering, 48, 1, 39-44.

10. Chang T.Y., Liu C.S., Bao B.Y., Li S.F., Chen T.I., LiN Y.J. (2011), Characterization of road traffic noise exposure and prevalence of hypertension in Central Taiwan, Science Total Environment, 409, 1053-1057.

11. Davies H., Kamp I.V. (2012), Noise and cardiovascular disease: a review of the literature 2008-2011, Noise Health, 14, 287-291.

12. Dintrans A., Préndez M. (2013), A method of assessing measures to reduce road traffic noise: A case study in Santiago, Chile, Applied Acoustics, 74, 14861491.

13. EU's Future Noise Policy, WG2-Dose/Effect, Position paper on dose response relationships between transportation noise and annoyance, 2002, http://ec.europa.eu/environment/noise/pdf/noise_expert_network.pdf [access on 02.03.2016].

14. Fiedler P.E.K., Zannin P.H.T. (2015), Noise mapping as tool for urban planning, Journal of Scientific and Industrial Research, 74, 114-116.

15. Garg N., Kumar A., Maji S. (2013), Significance and implications of airborne sound insulation criteria in building elements for traffic noise abatement, Applied Acoustics, 74, 1429-1435.

16. Garg N., Kumar A., Maji S. (2014a), Parametric sensitivity analysis of factors affecting sound insulation of double glazing using Taguchi method, Applied Acoustics, 74, 1406-1413.

17. Garg N., Kumar A., Maji S. (2014b), Parametric sensitivity analysis of factors affecting the sound insulation of multi-layered building elements, Archives of Acoustics, 39, 2, 165-176.

18. Garg N., Kumar A., Saini P.K., Maji S. (2015a), $A$ retrospective view of ambient noise standards in In- dia: Status and proposed revision, Noise Control Enginering Journal, 63, 266-278.

19. Garg N., Maji S. (2014), A critical review of principal traffic noise models: Strategies and implications, Environmental Impact Assessment Review, 46, 68-81.

20. Garg N., Maji S. (2016), A retrospective view of noise pollution control policy in India: Status, Proposed Revisions and Control Measures, Current Science Journal, 111, 1, 29-38.

21. Garg N., Mangal S.K., Saini P.K., Dhiman P., MAJi S. (2015b), Comparison of ANN and analytical models in traffic noise modelling and predictions, Journal of Acoustic Australia, 43, 179-189.

22. Garg N., Saxena T.K., Maji S. (2015c), Long-term versus short-term noise monitoring: Strategies and implications in India, Noise Control Engineering Journal, 63, 26-35.

23. Garg N., Sharma O., Maji S. (2011), Experimental investigations on sound insulation through single, double and triple window glazing for traffic noise abatement, Journal of Scientific and Industrial Research, 78, $471-478$.

24. Garg N., Sharma O., Mohanan V., Maji S. (2012), Passive noise control measures for traffic noise abatement in Delhi, India, Journal of Scientific and Industrial Research, 71, 226-234.

25. Garg N., Sinha A.K., Gandhi V., Bhardwaj R.M., Akolkar A.B. (2016), A pilot study on establishment of ambient noise monitoring network across the major cities of India, Applied Acoustics, 103, 20-29.

26. Garg N., Soni K., Saxena T.K., Maji S. (2015d), Applications of Autoregressive integrated moving average (ARIMA) approach in time-series prediction of traffic noise pollution, Noise Control Enginering Journal, 63, 182-194.

27. Garg N., Vishesh, Maji S. (2015e), Fuzzy TOPSIS approach in selection of optimal noise barrier for traffic noise abatement, Archives of Acoustics, 40, 4, 453-467.

28. Hammer M.S., Swinburn T.K., Neitzel R.L. (2014), Environmental noise pollution in the Unites States: developing an effective public health response, Environmental Health Perspectives, 122, 115-119.

29. http://www.cpcbnoise.com [access on 01.03.2016].

30. Jamir L., Nongkyrnuh B., Gupta S.K. (2014), Community noise pollution in Urban India: Need for public heath action, Indian Journal of Community Medicine, 39, 8-12.

31. Kim R., van den Berg M. (2010), Summary of night noise guidelines for Europe, Noise Health, 12, 47, 6163.

32. Kumar K., Parida M., Katiyar V.K. (2014), Optimized height of noise barrier for non-urban highway 
using artificial neural network, International Journal of Environment Science and Technology, 11, 719-730.

33. Lee S.W., Chang S.I., Park Y.M. (2008), Utilizing noise mapping for environmental impact assessment in a downtown redevelopment area of Seoul, Korea, Applied Acoustics, 69, 704-714.

34. Li B., TAO S., Dawson R.W. (2002), Evaluation and analysis of traffic noise from the urban main roads in Beijing, Applied Acoustics, 63, 1137-1142.

35. Mandal P.K., Bandyopadhyay A. (2014), Case study from West Bengal, India: Management of noise levels during festival time in Kolkata and Howrah Municipal Corporation Areas from 2002 to 2011, Environmental Quality Management, 23, 13-32.

36. McAlexander T.P., Gershon R.R.M., Neitzel R.L. (2015), Street-level noise in an urban setting: assessment and contribution to personal exposure, Environmental Health, 14, 18.

37. Meiarashi S., Ishida M. (1996), Noise reduction characteristics of porous elastic road surface, Applied Acoustics, 47, 239-250.

38. Miedema H.M., Vos H. (1998), Exposure-response relationships for transportation noise, Journal of Acoustical Society of America, 104, 3432-3445.

39. Ministry of Environment and Forests, Government of India, No. 14 of 1981, [29/03/1981] The Air (Prevention and Control of Pollution) Act, 1981, amended 1987. http://www.moef.nic.in/legis/air/air1.html [access on 01.03.2016].

40. Mohanan V., Sharma O., Garg N. (2010), Noise control measures for proposed Commonwealth Games Village near Noida Morr, NPL Tech. Report No. AC.C.07(4)-01.

41. Moriallas J.M.B., Escobar V.G., Sierra J.A.M., Gomez R.V., Carmona J.T. (2002), An environmental noise study in the city of Caceres, Spain, Applied Acoustics, 63, 1061-1070.

42. Murphy E., King E.A. (2010), Strategic environmental noise mapping: Methodological issues concerning the implementation of the EU Environmental Noise Directive and their policy implications, Environmental International, 36, 290-298.

43. Murphy E., KIng E.A. (2011), Scenario analysis and noise action planning: Modelling the impact of mitigation measures on population exposure, Applied Acoustics, 72, 487-494.

44. Murphy E., King E.A., Rice H.J. (2009), Estimating human exposure to transport noise in central Dublin, Ireland, Environmental International, 35, 2, 298-302.

45. NAISH D. (2010), A method of developing regional road traffic noise management strategies, Applied Acoustics, 71, 640-652.
46. National Ambient Noise Monitoring Network (2011), Information Brochure, ENVIS Newsletter, Central Pollution Control Board, India, http://cpcbenvis.nic.in/envis_newsletter/ENVIS\%20 newsletter.pdf [access on 02.03.2016].

47. Nijland R., Vos E., Hooghwerff J. (2003), The Dutch Noise Innovation Program Road Traffic (IPG), Proceedings of 32nd International Congress and Exposition on Noise Control Engineering, Internoise, Seogwipo, Korea, Paper No. 591.

48. Noise Pollution (Regulation and Control) Rules (2000), Ministry of Environment \& Forests, India, http://envfor.nic.in/downloads/public-information/noise-pollution-rules-en.pdf.

49. ÖHrströм E. (2004), Longitudinal surveys on effects of changes in road traffic noise-annoyance, activity disturbances, and psycho-social well-being, Journal of Acoustical Society of America, 115, 719-729.

50. Oishi N., Schacht J. (2011), Emergency treatments for noise-induced hearing loss, Expert Opinion on Emergency Drugs, 16, 2, 235-245.

51. Olayinka O.S. (2013), Effective noise control measures and sustainable development in Nigeria, World Journal of Environmental Engineering, 1, 5-15.

52. Ouis D. (2001), Annoyance from road traffic noise: A review, Journal of Environmental Psychology, 21, 101-120.

53. Pandya G.H. (2002), A comprehensive investigation of noise exposure in and around an integrated iron and steel works, American Industrial Hygiene Association 63, $2,172-177$.

54. Pathak V., Tripathi B.D., Mishra V.K. (2008), Evaluation of traffic noise pollution and attitudes of exposed individuals in working place, Atmospheric Environment, 42, 3892-3898.

55. Rasmussen B. (2010), Sound insulation between dwellings-Requirements in building regulations in Europe, Applied Acoustics, 71, 373-385.

56. Schomer P.D. (2002), On normalizing DNL to provide better correlation with response, Sound and Vibration, pp. 14-23, http://www.schomerandassociates.com/pdfs/NormalizingDNL.pdf [access on 01.03.2016].

57. Schomer P.D. (2005), Criteria for assessment of noise annoyance, Noise Control Enginering Journal, 53, 132-144.

58. Selander J., Nilsson M.E., Bluhm G., RosenLund M., Lindqvist M., Nise G., Pershagen G. (2009), Long-term exposure to road traffic noise and myocardial infarction, Epidemiology, 20, 2, 272-279.

59. SGS Weather and Environmental Systems Pvt. Ltd., India, http://www.sgsweather.com [access on 02.03.2016]. 
60. Sinha S., Sridharan P.V. (2003), Present and future assessment of noise level in the Neyveli region Journal of Environmental Studies and Policy, 2, 1-13.

61. Steele C. (2001), A critical review of some traffic noise prediction models, Applied Acoustics, 62, 271287.

62. To W.M, Mak C.M., Chung W.L. (2015), Are the noise levels acceptable in a built environment like Hong Kong?, Noise and Health, 17, 79, 429-439.

63. Tyagi V., Kumar K., Jain V.K. (2006), A study of the spectral characteristics of traffic noise attenuation by vegetation belts in Delhi, Applied Acoustics, 67, 926-935.

64. Tyagi V., Kumar K., Jain V.K. (2013), Road traffic noise attenuation by vegetation belts at some sites in the Tarai Region of India, Archives of Acoustics, 38, 3, 389-395.

65. U.S Department of Housing and Urban Development (1984), Environmental Criteria and Standards, 24 CFR
Part 51, V, 12 July, 1979, amended by 49FR 880, 6 January, 1984.

66. Watts G.R., Chandler-Wilde S.N., Morgan P.A. (1999), The combined effects of porous asphalt surfacing and barriers on traffic noise, Applied Acoustics, $\mathbf{5 8}, 351-377$.

67. WHO-JRC (2011), Burden of disease from environmental noise-quantification of healthy life years last in Europe, European Center for Environment and Health, JRC EU, http://www.euro.who.int/_data/assets/pdf_file/0008/136466/e94888.pdf [access on 02.03.2016].

68. World Health Organization (2009), Night Noise Guidelines for Europe, Copenhagen, Denmark: The World Health Organization Regional Office for Europe, http://www.euro.who.int/_data/assets/pdf_file/0017/ 43316/E92845.pdf. [access on 02.03.2016].

69. www.geonica.com [access on 02.03.2016].

70. Zannin P.H.T., Diniz F.B., Barbosa W.A. (2002), Environmental noise pollution in the city of Curitiba, Brazil, Applied Acoustics, 63, 351-358. 